\title{
Conjunctivitis in Elementary Schools
}

By DORLAND J. DAVIS, M. D., and VIRGINIA D. HINES, B. S.

As a part of an epidemiological investigation of conjunctivitis due to bacteria of the genus Hemophilus, in Thomas County, Ga., a study of the occurrence of the disease was made in children attending 12 elementary schools ${ }^{1}$ accessible to uniform observation.

In this area, as well as in many other parts of the southern United States, acute conjunctivitis is a common affliction of children and is known as "sore eyes" or "gnat sore eyes." Bacteriological studies in Texas (1) revealed the presence of Hemophilus aegyptius or KochWeeks bacillus (2), and Hemophilus influenzae in a significant number of cultures of the conjunctiva. These species have also been found in the current studies in Thomas County.

In addition to the bacteriological studies of cases to be reported later, an effort was made to assess the importance of conjunctival disease among children attending the schools of this region. Principals and teachers of the 12 schools, 6 white and 6 Negro, were asked to keep records of absenteeism due to conjunctivitis and of children with conjunctival symptoms attending schools. The analysis of these records forms the basis of this report.

Thomas County, located in southwestern Georgia, had a recorded population of 33,903 (approximately 45 percent Negro), according to the preliminary figures of the $1950 \mathrm{U}$. S. census. Agriculture and lumbering are the chief industries. Thomasville (population 14,446, preliminary 1950 U. S. census figures) is the largest town and serves as a commercial center for the area. Observations were made on children attending two of the three elementary schools for white children and both the elementary schools for Negro children in

\footnotetext{
${ }^{1}$ One school, the white elementary school of Barwick, was actually located just across the county line in Brooks County, Ga.
}

Thomasville. Most of these children lived in Thomasville proper, but about one-third lived in nearby rural or semirural areas and were transported to school by buses.

Outside of Thomasville nearly all children attend consolidated schools in the various nearby communities and are transported to and from their homes by bus. The study included observations on children attending both white and Negro schools (grades 1 to 11) in four other Georgia communities: Boston (population 1,032, preliminary figures 1950 U. S. census); Barwick (population 500, unofficial census); Meigs (population 1,083, preliminary figures 1950 U. S. census) ; and Ochlochnee (population 450, unofficial census). Most of the children attending these schools live in rural areas and the communities themselves are small or semirural. No studies were made of the 8 other consolidated schools and 11 one-room Negro schools in the county.

\section{Collection of Data}

The data were collected under the direct supervision of a Public Health Service nurse who was participating in the field work of the investigation. The information was actually recorded by the teachers of each room on forms specially prepared for this phase of the study. These forms were collected at 3-week intervals during the school term (October 10, 1949, to December 19, 1950), thus providing records

Dr. Davis is with the National Microbiological Institute of the National Institutes of Health, Public Health Service, Bethesda, Md. Miss Hines is with the Communicable Disease Center of the Public Health Service, assigned to the Thomasville Station section at Thomasville, Ga. 
Table 1. Conjunctivitis in grades 1, 2, and 3 of 12 selected schools, by month, October 1949 through December 1950

\begin{tabular}{|c|c|c|c|c|c|c|c|c|c|c|c|c|}
\hline & \multicolumn{3}{|c|}{1949} & \multicolumn{9}{|c|}{1950} \\
\hline & October & $\begin{array}{c}\text { Novem- } \\
\text { ber }\end{array}$ & $\begin{array}{c}\text { Decem. } \\
\text { ber }\end{array}$ & January & $\underset{\text { ary }}{\text { Tebru- }}$ & March & $\Delta \mathrm{prn}$ & May & $\underset{\text { ber }}{\text { Septem:- }}$ & October & $\underset{\text { ber }}{\text { Novem }}$ & Decem- \\
\hline $\begin{array}{l}\text { Total enrollment, pupil- } \\
\text { days }\end{array}$ & 17,799 & 38,643 & 22,888 & 42,543 & 38,504 & 43,012 & 34,061 & 30,482 & 30,718 & 89,980 & 36,682 & 21,687 \\
\hline $\begin{array}{l}\text { Absences per } 1,000 \text { pupil- } \\
\text { days of enrollment: } \\
\text { All causes } \\
\text { Conjunctivitisis } \\
\text { Pupil-days absent presum- } \\
\text { ably due to conjunc- } \\
\text { tivitis, per 1,000 pupil- } \\
\text { days of absences from } \\
\text { all causes } \\
\text { Pupil-days present with } \\
\text { conjunctivitis observed } \\
\text { in school per } 1,000 \text { pupil- } \\
\text { days of attendance... }\end{array}$ & $\begin{array}{c}158.5 \\
17.0\end{array}$ & $\begin{array}{r}66.5 \\
5.1\end{array}$ & $\begin{array}{r}68.3 \\
.8\end{array}$ & $\begin{array}{r}71.8 \\
1.4\end{array}$ & $\begin{array}{r}70.6 \\
.7\end{array}$ & $\begin{array}{r}92.5 \\
.2\end{array}$ & $\begin{array}{r}84.6 \\
.4\end{array}$ & $\begin{array}{r}100.2 \\
.3\end{array}$ & $\begin{array}{r}152.0 \\
16.7\end{array}$ & $\begin{array}{l}78.3 \\
12.5\end{array}$ & $\begin{array}{r}66.7 \\
1.4\end{array}$ & $\begin{array}{r}90.6 \\
2.6\end{array}$ \\
\hline
\end{tabular}

of more than a year's observations. The teachers were asked to list the name, age, and sex of each child in the room, record each day of absence from any cause, each day of absence due to conjunctivities, and each day that a child attended school while having conjunctival symptoms apparent to the teacher. This method of collecting information has many deficienciesthe number of different individuals recording the data, uncertainty of the cause of absence, the difficulty encountered by medically untrained persons in determining whether a child had signs of conjunctival disease, and some irregularity in recording data because of the press of teaching duties. A comparison of our records of total absences with the regular school reports of average daily attendance revealed a close agreement, but the records for the incidence of conjunctivitis were probably less accurate. Nevertheless, crude as they may be, the records do serve as an index of the extent of the problem of conjunctivitis in school children of Thomas County.

For analysis, the data were tabulated on the basis of pupil-days experience per month. The total number of children enrolled in a room was multiplied by the number of school days per month to give the total pupil-days of enrollment for that room or grade. The total of pupil-days was corrected by additions and subtractions in number of pupil-days for individuals entering or withdrawing from school dur- ing the period. Likewise, absences were calculated on number of school days absent for each child. Rates could then bo computed in terms of pupil-days per monthly time interval for the desired groupings of grades. Final tables, by months, were made of the experience of children attending the first, second, and third grades, which included those aged 6, 7, and 8 years, and in some instances, especially in Negro schools, some children 9 and 10 years of age. Tabulations of the data for grades 4 to 6 were made on an annual basis only and not adjusted to months because of the small numbers involved.

\section{Analysis of Data}

The experience with conjunctivitis in the first 3 grades of the 12 selected schools during the period of study is shown in table 1.

It would appear from the data presented that the rate of absences from conjunctivitis is highest in September and October and declines thereafter. The rate of absence from all causes (table 1) was highest in the spring months, but not of sufficient magnitude to affect significantly the seasonal pattern of the proportion of absences due to conjunctivitis.

Table 2 presents data on the annual "disability" rate, by grades, in the individual schools and in all schools of the study.

The children in grades 1 to 3 were more af- 
fected than those in grades 4 to 6 , as judged by the rate of absences and of observed conjunctivitis in those attending all 12 schools. Although the data are not presented here, cases were observed less frequently in grades above the sixth and were seen occasionally in teachers. According to these data the rate of absenteeism due to conjunctivitis was higher in the white schools than in the Negro schools for both grade groupings. This is also true for the observed incidence of conjunctivitis in those attending schools outside of Thomasville but is not evident in the Thomasville schools. Although there does not appear to be a differ-

Table 2. Annual "disability" rate of absence due to conjunctivitis and presence in school with observed conjunctivitis, per 1,000 days of enrollment, January through December 1950

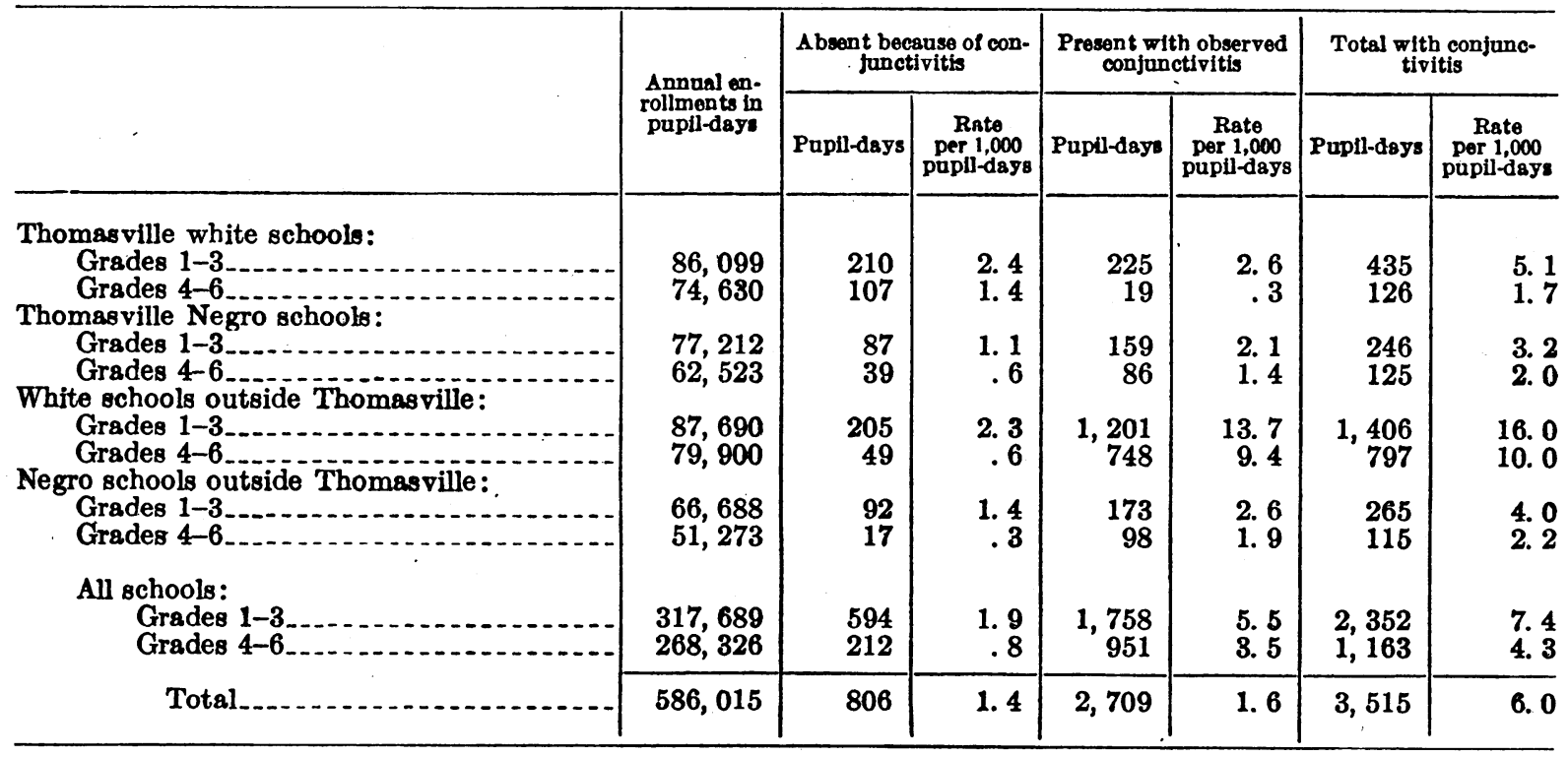

ence in absenteo rates between schools in Thomasville and outside Thomasville for white and Negro and for the grade groups, a higher rate of observed diseases was recorded for those in attendance at the schools outside of Thomasville. The total rates for conjunctivitis reflect this difference also. Usually the Thomasville school children with the disease in the acute stage were sent home. But in other schools where the children were dependent on bus transportation it was not possible to send them home, and they remained in school.

The figures indicate the extent of the problem. They show that a total of 806 pupil-days of absence were due to conjunctivitis. Also 2,709 pupil-days of conjunctival disease were observed in children attending school in grades 1 to 6 of the 12 schools under observation during 1950.

The records were also analyzed to show the actual number of individual pupils who were absent because of conjunctivitis and who at- tended school with observed conjunctivitis each month from November 1949 through December 1950, and the total individual attack rate per 100 pupils enrolled. These are presented in table 3 for the first three grades by school groups. In preparing these data, individuals with conjunctivitis were counted only once each month. If they were recorded as both absent and present with conjunctivitis, they were counted as absent during that month. The highest attack rate occurred during the month of September in the group including four white schools outside of Thomasville when about 1 of every 3 or 4 pupils was affected by the disease. In the same month there appeared to be a lower incidence in the Thomasville white schools with about 1 in 10 affected. Negro children were lees intensively attacked, and the rate for both races was lower in Thomasville schools than in schools outside Thomasville. Although the rates were highest in all groups in September, October, and November, cases were observed 
Table 3. Number of pupils absent because of conjunctivitis, number present with observed conjunctivitis, and total attack rate per 100 pupils enrolled, grades 1, 2, and 3 of 12 selected schools, November 1949 through December 1950

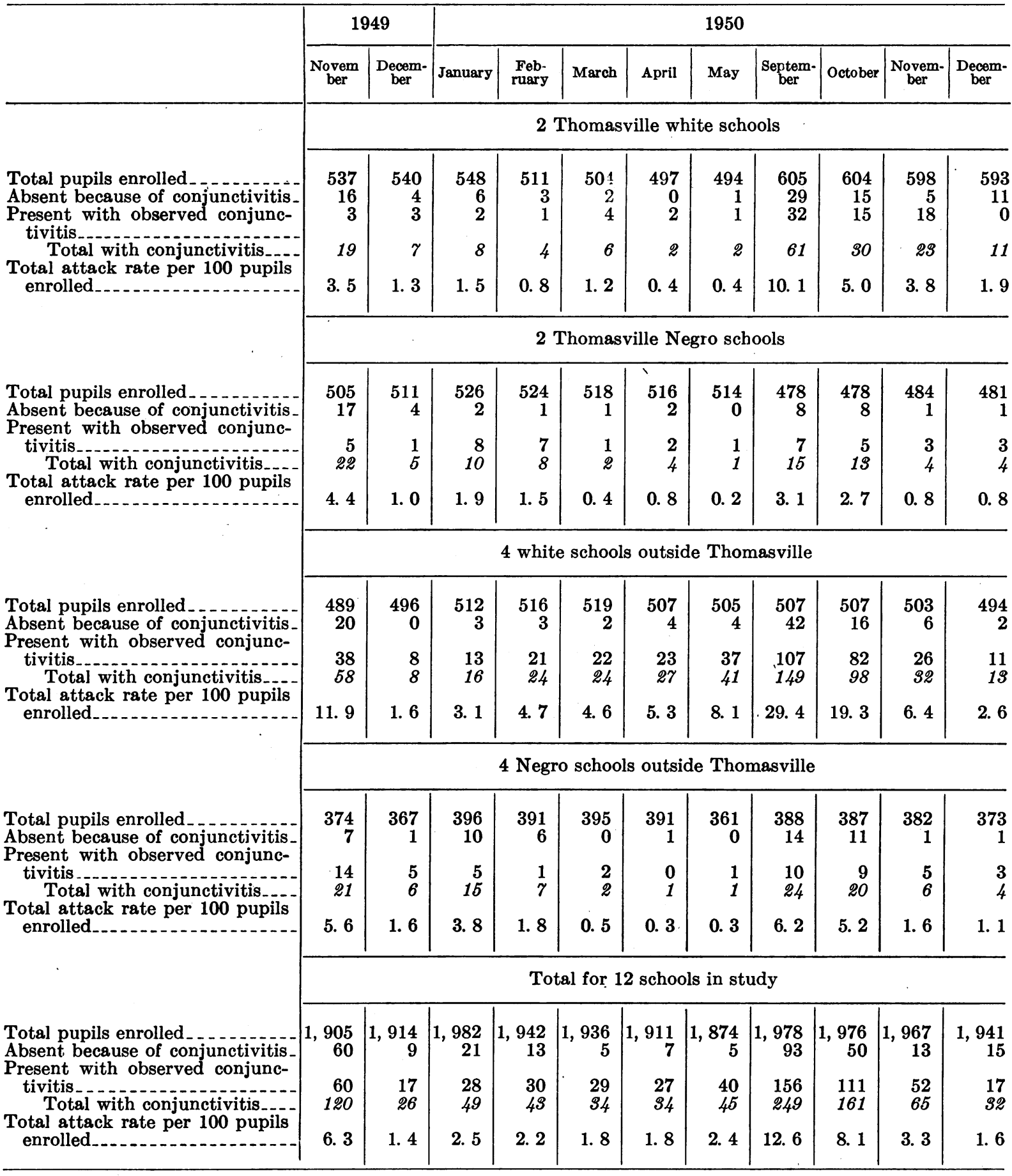

throughout the year. In white schools outside of Thomasville, the rates gradually increased from a low of 1.6 percent in December
1949 to 8.1 percent in May 1950 when the schools closed for the summer.

In a study of absenteeism in New Haven, 
Conn., schools, Linde and associates (3) recorded data on absences due to diseases and disorders of the eye for 1927 and for 1948, calculated in pupil-days. Though their data are not strictly comparable to ours because of inclusion of all eye diseases, and are of somewhat different age groupings, they show a very much lower annual rate, 0.30 per 1,000 pupildays in 1948, including all disorders of the eye, compared to our rate in Georgia, 7.4 per 1,000 pupil-days in grades 1 to 3 and 4.3 per 1,000 pupil-days in grades 4 to 6 . This emphasizes the relative importance of the problem in the schools of Thomas County and in other parts of the South where the disease occurs.

\section{Summary}

To assess the importance of conjunctivitis as a cause of absenteeism and disability in the school children of Thomas County, Ga., studies were made in six white and six Negro elementary schools of that county from October 1949 to December 1950. An analysis of the records of these studies on the basis of pupil-days experience shows that the highest incidence of the disease occurred during September and October when about 15 percent of all absences in pupildays was due to conjunctivitis.

When calculated in pupil-days, the rates of absence due to conjunctivitis and occurrence in children attending schools were higher in grades 1 to 3 than in grades 4 to 6 for both white and Negro children and higher in the white schools than in the Negro schools. This does not necessarily reflect differences in numbers of individuals affected. The records indicate also that there was more conjunctival disease in white schools located outside Thomasville than in white schools in Thomasville, though this is not reflected in the rate of absences due to conjunctivitis. In grades 1 to 6 of the 12 schools under study during the school year 1950 , a total of 806 pupil-days of absence was ascribed to conjunctivitis, and 2,709 pupil-days of conjunctival disease were observed in children attending school.

The data do not represent a true incidence of the disease in these school children because of the methods used in the collection of records. But they are useful as an indication of the magnitude of the problem, of the seasonal occurrence, and of the white and Negro incidence in that county.

\section{ACKNOWLEDGMENTS}

The assistance and cooperation of Dr. John D. Stillwell, commissioner of health, Thomas County health department, W. H. Rehberg, superintendent, Thomas County schools, and R. D. Blakeney, superintendent, Thomasville city schools, is acknowledged. We particularly appreciate the continuous assistance and interest of the many individual teachers and principals of the 12 schools in which the studies were undertaken.

\section{REFERENCES}

(1) Davis, D. J., and Pittman, M:: Acute conjunctivitis caused by Hemophilus. Am. J. Dis. Child. 79: 211-219 (1950).

(2) Pittman, M., and Davis, D. J.: Identification of the Koch-Weeks bacillus. J. Bact. 59: 413-426 (1950).

(3) Linde, J. I., Gelperin, A., Granoff, M. A.: Causes of absenteeism in New. Haven schools. Followup after 21 years. Pub. Health Rep. 65: 17371744 (1950).

\section{Birth Registration Has Improved in Past Decade}

The proportion of infants without birth certificates has been reduced by threequarters during the past decade, preliminary results of a nation-wide survey of birth registration indicate. This survey-the second of its kind-found that almost 98 percent of the. babies born in the first 3 months of 1950 were registered as compared with 92.5 percent in 1940 , when the first national test was made.

The recent birth registration test was conducted by the Public Health Service and State health departments, in cooperation with the Bureau of the Census, Department of Commerce. It involved matching birth certificates with census records.

The primary purpose of the nation-wide test was to measure the completeness of birth registration in States and local areas on a comparable basis. The results will help registrars to spot the problem areas and to determine the reasons for failure to register births. 